\title{
Removal of Chromium from Synthetic Wastewater Using Modified Maghemite Nanoparticles
}

\author{
Shishir Kumar Behera ${ }^{1, *(\mathbb{D}}$, Srijan Sahni ${ }^{1}$, Gunjan Tiwari ${ }^{1}$, Aditi Rai ${ }^{1}$, Biswanath Mahanty ${ }^{2}{ }^{\mathbb{D}}$, \\ Ayi Vinati ${ }^{3}$, Eldon R. Rene ${ }^{4, *}$ and Arivalagan Pugazhendhi ${ }^{5}$ \\ 1 Industrial Ecology Research Group, School of Chemical Engineering, Vellore Institute of Technology, \\ Vellore 632014, Tamil Nadu, India; srijansahni@gmail.com (S.S.); gunjankumartiwari.5km@gmail.com (G.T.); \\ aditi84rai@gmail.com (A.R.) \\ 2 Department of Biotechnology, Karunya Institute of Technology \& Sciences, Coimbatore 641 114, Tamil Nadu, \\ India; bmahanty@gmail.com \\ 3 Department of Chemical Engineering, GMR Institute of Technology, Rajam 532 127, Srikakulam, India; \\ vinati.ayi@gmail.com \\ 4 Department of Environmental Engineering and Water Technology, IHE Delft Institute for Water Education, \\ P. O. Box 3015, 2601 DA Delft, The Netherlands \\ 5 Innovative Green Product Synthesis and Renewable Environment Development Research Group, \\ Faculty of Environment and Labour Safety, Ton Duc Thang University, Ho Chi Minh City 758307, Vietnam; \\ arivalagan.pugazhendhi@tdtu.edu.vn \\ * Correspondence: shishir.kb@vit.ac.in (S.K.B.); e.raj@un-ihe.org (E.R.R.); Tel.: +91-416-220-2665 (S.K.B.)
}

Received: 31 March 2020; Accepted: 27 April 2020; Published: 2 May 2020

\begin{abstract}
The main aim of this study was to ascertain the removal of chromium ions from synthetic wastewater using modified maghemite nanoparticles (MNPs). Commercially available maghemite nanoparticles (NPs) $(<50 \mathrm{~nm})$ were modified using sodium dodecyl sulfate (SDS). The MNPs were characterized using a powder X-ray diffractometer (XRD) and Fourier transform infrared spectrophotometer (FTIR). Statistically designed batch experiments were carried out to evaluate the effects of various parameters, namely the $\mathrm{pH}$ of the solution, initial chromium concentration, and adsorbent dose, on the chromium removal efficiency (RE). The results from this study showed that the adsorbent dose had a synergistic effect on chromium RE, while $\mathrm{pH}$ and initial chromium concentration had antagonistic effects on the RE. An optimal chromium RE of 95.8\% was obtained at $\mathrm{pH}=2.6$, adsorbent dose $=5 \mathrm{~g} / \mathrm{L}$, and initial chromium concentration $=20 \mathrm{mg} / \mathrm{L}$. The analysis of variance (ANOVA) results showed that the model was significant, with high $F$ value $(F=80.07)$ and low $P$ value $(P=<0.001)$. Based on the results obtained from the experiments, the MNPs could be exploited as an efficient adsorbent for chromium removal from wastewater.
\end{abstract}

Keywords: chromium removal; maghemite nanoparticles; SDS; FTIR; XRD

\section{Introduction}

The three most common forms of chromium that exist in our environment are metallic $\left(\mathrm{Cr}^{0}\right)$, trivalent $\left(\mathrm{Cr}^{+3}\right)$, and hexavalent $\left(\mathrm{Cr}^{+6}\right)$. Metallic chromium does not occur naturally in elemental form. Trivalent chromium ion, $\mathrm{Cr}$ (III), is found in trace amounts in humans and is an essential nutrient for insulin, sugar, and lipid metabolism. Hexavalent chromium species $\left(\mathrm{Cr}^{+6}\right)$ are highly toxic agents that act as carcinogens, mutagens, and teratogens in different biological systems [1]. Hexavalent chromium is included in the World Health Organization's (WHO) list of 10 chemicals of major public health concern and the maximum level of total chromium in drinking water has been set as $0.05 \mathrm{mg} / \mathrm{L}$ [2]. The United States Environmental Protection Agency (USEPA) prescribes that the levels of chromium in water should be reduced to $0.1 \mathrm{mg} / \mathrm{L}$ using appropriate technologies [3]. 
Hexavalent chromium $\left(\mathrm{Cr}^{+6}\right)$ usually exists in wastewater in the form of oxyanions, such as chromate $\left(\mathrm{CrO}_{4}^{2-}\right)$ and dichromate $\left(\mathrm{Cr}_{2} \mathrm{O}_{7}{ }^{2-}\right)$, and does not precipitate easily using ordinary precipitation techniques. $\mathrm{Cr}(\mathrm{VI})$, a hazardous material, is also found in solution as the monomeric ions $\mathrm{H}_{2} \mathrm{CrO}_{4}{ }^{0}$, $\mathrm{HCrO}_{4}^{-}$(bichromate), and $\mathrm{CrO}_{4}{ }^{2-}$ (chromate), or as the dimeric ion $\mathrm{Cr}_{2} \mathrm{O}_{7}{ }^{2-}$ (dichromate) $[4,5]$. According to the literature, chemical redox followed by precipitation can be applied for $\mathrm{Cr}^{+6}$ removal from contaminated water streams [6].

In this work, adsorption technology was considered as the most promising technique for chromium removal from industrial wastewater. Hu et al. [7] reported the removal of chromium from industrial wastewater using maghemite nanoparticles as the adsorbent. This technique has been used in many industrial case studies, whereby various adsorbents were found to be effective for heavy metal removal $[1,8,9]$. In principle, adsorption not only removes heavy metals but also recoups and recycles them back into the industrial process [10]. The adsorbed material, which is either toxic or valuable, is recouped in a concentrated form for disposal or reuse. The solid adsorbent can often be regenerated for reuse [11]. Several natural and synthetic materials have been used as $\mathrm{Cr}(\mathrm{VI})$ adsorbents, such as activated carbons, biological materials, zeolites, chitosan, and industrial wastes [12-14]. However, these adsorbents also have several disadvantages and limitations, including high cost, low adsorption capacity, and difficulties associated with the separation and removal following the treatment steps. Therefore, in this study, maghemite $\left(\gamma-\mathrm{Fe}_{2} \mathrm{O}_{3}\right)$ was used as the adsorbent because of its high surface area, magnetic properties, and chemical stability [15]. Maghemite, a common magnetic material, is a promising environmentally friendly adsorbent for heavy metal removal because it is inexpensive, readily available, and it can be easily separated and recovered [16-18].

Various surface modification techniques have been used to suitably modify surface properties and study the resultant changes in adsorption efficiency. Nanoparticles (NPs) have been of special interest to researchers and scholars due to their magnetic properties, availability, and susceptibility to modification. For example, bentonite-supported zero-valent iron nanoparticles and imine functionalized magnetic nanoparticles have been exploited for the removal of $\mathrm{Cr}$ (VI) from landfill leachate and $\mathrm{Zn}^{2+}$ and $\mathrm{As}^{3+}$ from wastewater, respectively $[19,20]$. Based on a preliminary literature review, it was noticed that sodium dodecyl sulfate (SDS), a common synthetic anionic surfactant, has never been used before with NPs for heavy metal ion removal, despite its proven potential for substantially and suitably altering the surface properties of nanoparticles. In this study, the adsorption potential of NPs modified with SDS for chromium heavy metal ions was investigated.

NPs have been used in various fields, such as in cleaning applications, lubrication, stabilization of emulsions, preparation of nano- and microparticles, and even as model systems for biological membranes in protein research [21,22]. SDS molecules contain a 12-carbon saturated alkyl chain bound to a negatively charged sulfonate head $\left(-\mathrm{OSO}_{3}{ }^{-}\right)$, and therefore are structurally comparable to many bio-surfactants [23]. This makes them suitable for adsorption over the maghemite surface. To the best of our knowledge, NPs modified with SDS have not been used so far to study $\mathrm{Cr}^{+6}$ removal from wastewater. The main objectives of this study were to investigate the adsorption efficiency of modified maghemite nanoparticles (MNPs) for chromium removal and to determine their viability as an alternative for chromium removal from wastewater. The specific objectives of the present work are: (i) to synthesize MNPs using SDS and characterize them using XRD and FTIR; (ii) to determine the optimal process conditions for enhanced chromium removal; and (iii) to study the effects of $\mathrm{pH}$, adsorbent dosage, and initial concentration on chromium removal using MNPs.

\section{Materials and Methods}

\subsection{Sample Preparation}

Stock solution of chromium was prepared using $2.829 \mathrm{~g}$ of analytical grade $\mathrm{K}_{2} \mathrm{Cr}_{2} \mathrm{O}_{7}$ (Nice Chemicals, Chennai, India). This was dissolved in double-distilled water forming $250 \mathrm{mg} / \mathrm{L}$ of chromium stock solution and used within a month of preparation [24]. The sample chromium solutions 
for all experiments were prepared by diluting the stock solution with distilled water to achieve the desired concentration levels. The required $\mathrm{pH}$ was adjusted by using either $0.1 \mathrm{~N} \mathrm{HCl}$ or $\mathrm{NaOH}$.

\subsection{Adsorbent Preparation and Characterization}

The NPs obtained from Sigma-Aldrich (Bengaluru, India), after suitable modification, were used as the adsorbent. SDS was used to modify the surface characteristics of NPs, according to the method described elsewhere [25]. In this method, different volumes of 5\% (w/v) SDS solution $(1,2,3$, and 4 $\mathrm{mL}$ ) were tested to identify the most effective concentration for chromium removal. The SDS solution was added to $0.1 \mathrm{~g}$ of NPs and stirred for $90 \mathrm{~s}$. Thereafter, the MNPs were separated using magnetic decantation and then washed with double-distilled water (4 times). After this step, drying was done overnight at $60^{\circ} \mathrm{C}$ in a hot air oven. The dried particles were crushed in a mortar and pestle (made of marble to avoid any external particle contamination).

To determine the suitable SDS concentration, the NPs $(0.1 \mathrm{~g})$ were added to $10 \mathrm{~mL}$ samples of $2000 \mathrm{mg} / \mathrm{L}$ of chromium solution at $\mathrm{pH}=5.0 \mathrm{in}$ a $250 \mathrm{~mL}$ flask and placed in an orbital shaker at 200 $\mathrm{rpm}$, at $\sim 35^{\circ} \mathrm{C}$ room temperature for $30 \mathrm{~min}$ [26]. Thereafter, magnetic decantation was done to the samples and the resulting solution was stored for further analysis. The concentration of chromium was determined using atomic absorption spectroscopy (AAS). It was observed that the most effective SDS concentration for chromium removal was $2 \mathrm{~mL}$. Hence, the NPs modified using $2 \mathrm{~mL}$ SDS were selected as the model adsorbent in this study.

FTIR analysis (IR Affinity-1 spectrophotometer, Japan) was done to determine the specific functionality of the NPs (Figure 1a) and MNPs (Figure 1b), respectively, in transmission mode. An average of 5 scans was collected for each measurement in the range of $400-4000 \mathrm{~cm}^{-1}$. The crystalline structure of these nanoparticles was characterized by XRD analysis (T-8 Brooker Advanced, Germany), operated at $30 \mathrm{kV}$ and a current of $40 \mathrm{~mA}$ with $\mathrm{Cu}-\mathrm{K} \alpha$ radiation $(\lambda=0.154 \mathrm{~nm})$. A scan mode was used to collect the $2 \theta$ data from $20^{\circ}$ to $90^{\circ}$. 

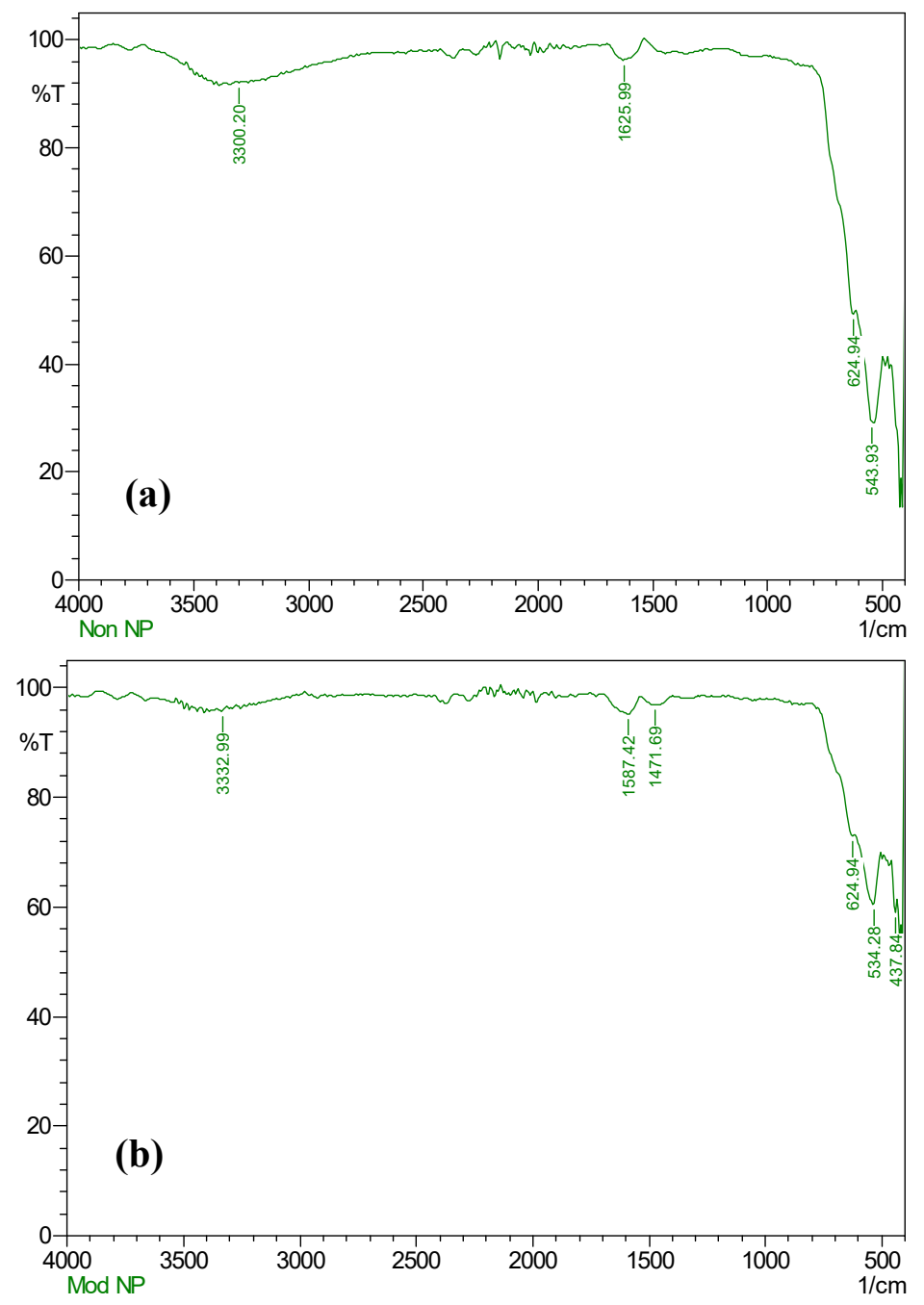

Figure 1. (a) Fourier transform infrared spectrophotometer (FTIR) analysis for maghemite nanoparticles (NPs). (b) FTIR analysis for modified maghemite nanoparticles (MNPs).

\subsection{Batch Adsorption Experiment and Chromium Analysis}

Batch experiments were conducted in $250 \mathrm{~mL}$ conical flasks (in duplicates) containing $20 \mathrm{~mL}$ of chromium solution of the desired concentration. Predetermined concentrations of adsorbents were added to these flasks. All the experiments were performed in an orbital shaker at room temperature $\left(\sim 35^{\circ} \mathrm{C}\right)$ and $200 \mathrm{rpm}$. The $\mathrm{pH}$ of the solution was monitored using a digital $\mathrm{pH}$ meter (Orion 3-star, Thermo Electron Corporation, USA). Based on the results from preliminary kinetic studies, a stirring time of $80 \mathrm{~min}$ was selected as the equilibrium time. Upon completion of the experiments, the separation of the liquid phase from the spent adsorbent was achieved by filtration using Whatman $42(2.5 \mu \mathrm{m})$ filter paper. The chromium concentration in the filtrate was measured using an atomic absorption spectrometer (Varian SPECTRA A240, USA). The current was $7.0 \mathrm{~mA}$, with the detection wavelength set at $357.9 \mathrm{~nm}$ and with a slit bandwidth of $0.2 \mathrm{~nm}$, as recommended by the manufacturer. The percentage of chromium removal was calculated using Equation (1):

$$
R E(\%)=\frac{C_{0}-C_{e}}{C_{0}} \times 100
$$

where $R E$ is the chromium removal efficiency (\%), $C_{0}$ and $C_{e}$ are the initial and final or equilibrium concentrations in the solution $(\mathrm{mg} / \mathrm{L})$, respectively. 
The adsorption equilibrium time was determined through preliminary experiments at an initial concentration of $20 \mathrm{mg} / \mathrm{L}, \mathrm{pH}$ of 6.0, and at room temperature over a period of $120 \mathrm{~min}$. The optimal contact time was found to be $80 \mathrm{~min}$. Then, $10 \mathrm{~mL}$ of solution was taken in six conical flasks of 250 $\mathrm{mL}$ capacity and $0.05 \mathrm{~g}$ of MNPs were added to the solution. The flasks were taken out at regular intervals from the shaker, as stated above, and the solution was separated using the standard magnetic decantation procedure.

\subsection{Experimental Design and Optimization of Parameters}

The experiment was designed with $\mathrm{pH}$, adsorbent dose, and initial concentration as the independent variables and the chromium $\mathrm{RE}$ as the dependent response variable. The $\mathrm{pH}$ and adsorbent dose ranges were selected based on previous research works [24,27]. The initial concentration was selected based on the prevailing chromium contamination in ground water in the surrounding areas [28]. In this work, a full-factorial central composite design (CCD) consisting of a complete $2^{\mathrm{k}}$ factorial design, $\mathrm{n}_{0}$ center point $\left(\mathrm{n}_{0}>1\right)$, and two axial points on the axis of each design variable at a distance of $\alpha=1.682$ from the design center was used [27]. Thus, a total of $N=2^{k}+2 k+n_{0}$ (where $k$ stands for number of factors and $\mathrm{n}_{0}$ for the number of times center point was replicated) design points was used in this work $\left(\mathrm{k}=3, \mathrm{n}_{0}=6\right)$. The center point replicates were chosen to verify any change in the estimation procedure as a measure of the precision property. The independent variables, experimental range, and levels for chromium removal are given in Table 1 . The optimum values of the test variables were obtained using the numerical point prediction tool in MINITAB (Version 16, PA, USA).

Table 1. Experimental variables and levels investigated by central composite design (CCD).

\begin{tabular}{cccccc}
\hline Variables & \multicolumn{5}{c}{ Coded Values } \\
\cline { 2 - 6 } & $\mathbf{- 1 . 6 8 2}$ & $\mathbf{- 1}$ & $\mathbf{0}$ & $\mathbf{1}$ & $\mathbf{1 . 6 8 2}$ \\
\hline $\mathrm{pH}\left(X_{1}\right)$ & 2.6 & 4 & 6 & 8 & 9.4 \\
Adsorbent dose $\left(X_{2}, \mathrm{~g} / \mathrm{L}\right)$ & 0.8 & 2.5 & 5 & 7.5 & 9.2 \\
Initial chromium concentration $\left(X_{3}, \mathrm{mg} / \mathrm{L}\right)$ & 3.2 & 10 & 20 & 30 & 36.8 \\
\hline
\end{tabular}

The experimental design matrix is shown in Table 2. Experiments 15-20 at the center point were used to calculate the experimental error, consistent with the sequential model sum of squares. The model selection was based on the highest order polynomials wherever the additional terms were important, and also because the models were not aliased. RSM was used to develop a correlation between the adsorption of chromium from solution to the adsorption of chromium by the MNPs. The data obtained from the experiments were used to fit a complete quadratic polynomial model through the CCD experiment, which helped to interpret the results in a statistically significant manner. 
Table 2. Experimental design matrix and results for adsorption of chromium.

\begin{tabular}{ccccccccc}
\hline \multirow{2}{*}{ Run } & \multicolumn{3}{c}{ Actual Level of Factors } & \multicolumn{2}{c}{ Coded Level of Factors } & \multicolumn{2}{c}{ Chromium RE (\%) } \\
\cline { 2 - 9 } & $\boldsymbol{X}_{\mathbf{1}}$ & $\boldsymbol{X}_{\mathbf{2}}(\mathrm{g} / \mathrm{L})$ & $\boldsymbol{X}_{\mathbf{3}}(\mathbf{m g} / \mathbf{L})$ & $\boldsymbol{X}_{\mathbf{1}}$ & $\boldsymbol{X}_{\mathbf{2}}$ & $\boldsymbol{X}_{\mathbf{3}}$ & Experimental & Predicted \\
\hline 1 & 4 & 2.5 & 10 & -1 & -1 & -1 & 80.54 & 84.38 \\
2 & 8 & 2.5 & 10 & 1 & -1 & -1 & 69.79 & 69.87 \\
3 & 4 & 7.5 & 10 & -1 & 1 & -1 & 92.72 & 94.54 \\
4 & 8 & 7.5 & 10 & 1 & 1 & -1 & 90.36 & 89.56 \\
5 & 4 & 2.5 & 30 & -1 & -1 & 1 & 67.46 & 67.44 \\
6 & 8 & 2.5 & 30 & 1 & -1 & 1 & 52.35 & 49.72 \\
7 & 4 & 7.5 & 30 & -1 & 1 & 1 & 93.82 & 92.92 \\
8 & 8 & 7.5 & 30 & 1 & 1 & 1 & 82.2 & 77.54 \\
9 & 2.64 & 5 & 20 & -1.682 & 0 & 0 & 95.48 & 93.94 \\
10 & 9.36 & 5 & 20 & 1.682 & 0 & 0 & 73.95 & 74.85 \\
11 & 6 & 0.795 & 20 & 0 & -1.682 & 0 & 49.58 & 49.69 \\
12 & 6 & 9.204 & 20 & 0 & 1.682 & 0 & 88.34 & 87.69 \\
13 & 6 & 5 & 3.182 & 0 & 0 & -1.682 & 92.81 & 91.28 \\
14 & 6 & 5 & 36.82 & 0 & 0 & 1.682 & 72.15 & 72.98 \\
15 & 6 & 5 & 20 & 0 & 0 & 0 & 80.85 & 80.99 \\
16 & 6 & 5 & 20 & 0 & 0 & 0 & 80.89 & 80.99 \\
17 & 6 & 5 & 20 & 0 & 0 & 0 & 80.84 & 80.99 \\
18 & 6 & 5 & 20 & 0 & 0 & 0 & 80.87 & 80.99 \\
19 & 6 & 5 & 20 & 0 & 0 & 0 & 83.49 & 80.99 \\
20 & 6 & 5 & 20 & 0 & 0 & 0 & 81.02 & 80.99 \\
\hline
\end{tabular}

Commonly used statistical analysis tests were performed on the experimentally obtained \% removal of chromium for the analysis of variance (ANOVA) to determine the variables that have a significant effect, i.e., either antagonistic or synergistic [29]. The response surface and contour plots were also obtained using the software by choosing appropriate internal settings for the process parameters.

\section{Results}

\subsection{Characterization of NPs and MNPs}

FTIR analysis determined the specific functionality of the NPs (Figure 1a) and MNPs (Figure 1b). The most abundant functional group observed in our samples was the hydroxyl group, with broad bands at 3300 and $3332 \mathrm{~cm}^{-1}$ (OH stretching mode), respectively, and bands at 1625 and $1587 \mathrm{~cm}^{-1}(\mathrm{OH}$ bending modes), respectively. The Fe-O stretching bands appeared at 624.94 and $543.93 \mathrm{~cm}^{-1}$ for both the samples. In the case of MNPs, as shown in Figure 1b, the sulphate ion band appeared at 437.84 $\mathrm{cm}^{-1}$, confirming that the maghemite had been successfully modified [30].

The results of XRD analysis of NPs and MNPs given in Figure 2a,b reveals that all diffraction peaks are consistent with the standard structure of maghemite. 

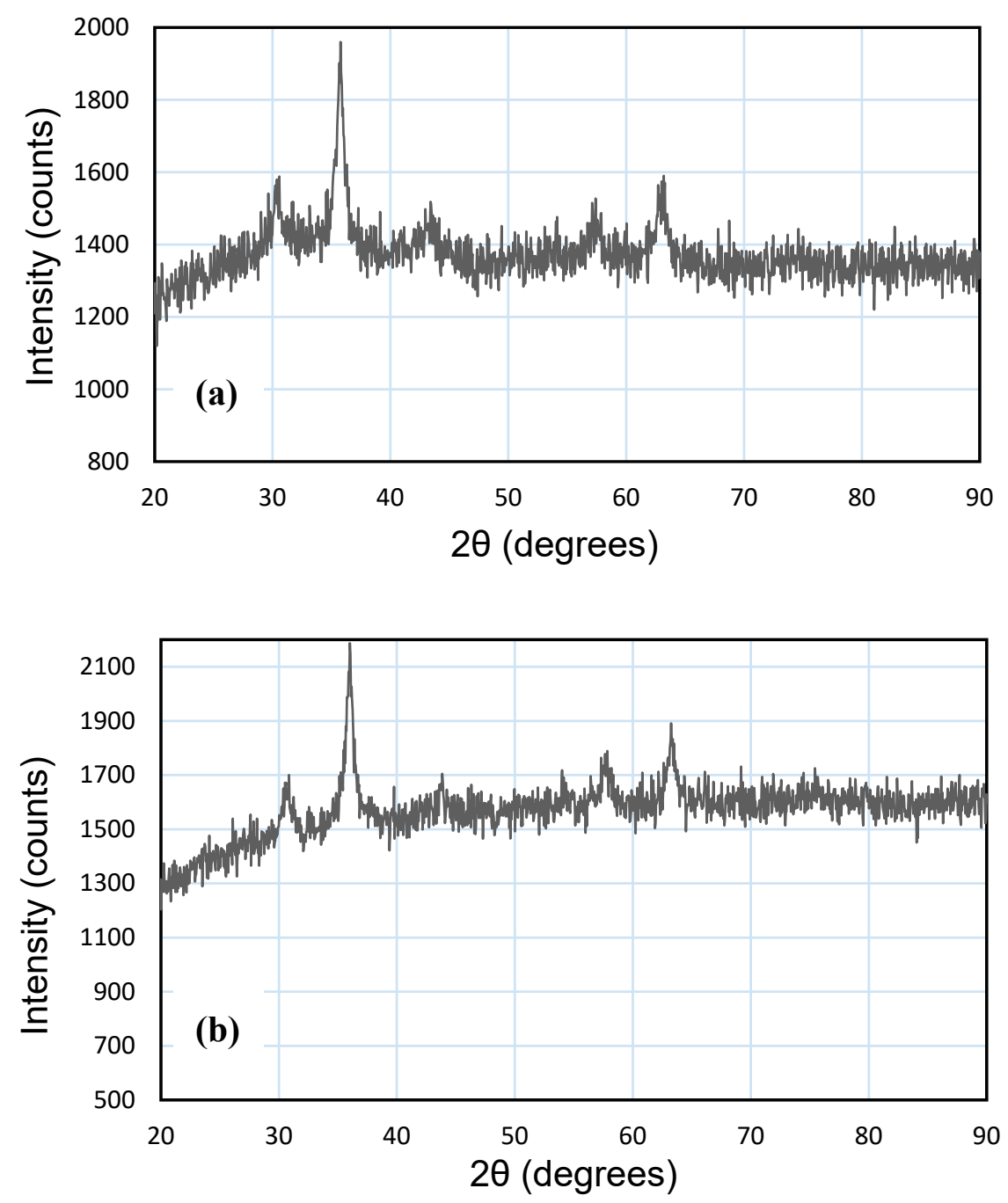

Figure 2. (a) X-ray diffraction (XRD) analysis for maghemite nanoparticles (NPs). (b) XRD analysis for modified maghemite nanoparticles (MNPs).

\subsection{Development of the Regression Model and Statistical Analysis}

The data obtained from the experiments were used to fit a complete quadratic polynomial model, as given in Equation (2). The maximum chromium RE was found to be $95.5 \%$.

$$
\begin{gathered}
Y=91.74-6.22 X_{1}+7.35 X_{2}-0.78 X_{3}+0.304 X_{1}^{2}-0.696 X_{2}^{2}+0.004 X_{3}^{2} \\
+0.297 X_{1} X_{2}-0.085 X_{2} X_{3}+0.117 X_{1} X_{3}(2)
\end{gathered}
$$

where $Y$ is the \% removal of chromium, $X 1$ is the $\mathrm{pH}, \mathrm{X} 2$ is the adsorbent dose $(\mathrm{g} / \mathrm{L})$, and $\mathrm{X} 3$ is the initial concentration $(\mathrm{mg} / \mathrm{L})$, respectively.

In this study, the values of $R^{2}$ and $R^{2}$ (adj) were found to be $99.24 \%$ and $98.55 \%$, respectively, confirming the accuracy of the model. From ANOVA, it was determined that the model was found to be significant, as it has a high $F$ value $(F=80.07)$ and low $P$ value $(P=<0.001)$. It was also observed that the linear effects were significant with high $F$ and low $P$ values (Table 3 ). The regression coefficients, $t$ values, and $P$ values for all the linear, squared, and interaction effects of the parameters are given in Table 4 . Table 4 can be interpreted as follows: (i) the coefficient of adsorbent dose $\left(X_{2}\right)$ had a highly significant positive effect $(P<0.05)$ on chromium removal, (ii) the coefficients of linear effects due to $\mathrm{pH}\left(X_{1}\right)$ and initial chromium concentration $\left(X_{3}\right)$ were negatively significant, (iii) the coefficients due to the squared effects of $\mathrm{pH}$ had significant positive effects on chromium removal with $P<0.05$, (iv) 
the coefficient of squared effects of initial chromium concentration $(X 3)$ was insignificant $(P<0.4)$ on the chromium $\mathrm{RE}(\mathrm{Y})$, and $(\mathrm{v})$ the coefficients due to the interaction between $\mathrm{pH} \times$ adsorbent dose and adsorbent dose $\times$ initial chromium concentration had positive effects $(P<0.005)$ on chromium removal.

Table 3. ANOVA of chromium removal.

\begin{tabular}{ccccccc}
\hline Source & Sum of Squares & Degree of Freedom & Mean Square & $\boldsymbol{F}$ Value & $\boldsymbol{P}$ Value & Remarks \\
\hline Regression & 2976.04 & 9 & 330.67 & 144.94 & 0 & Significant \\
Linear & 2546.38 & 3 & 848.79 & 372.05 & 0 & Significant \\
$X_{1}$ & 423.48 & 1 & 423.48 & 185.63 & 0 & Significant \\
$X_{2}$ & 1739.86 & 1 & 1739.86 & 762.64 & 0 & Significant \\
$X_{3}$ & 383.03 & 1 & 383.03 & 167.9 & 0 & Significant \\
Square & 320.03 & 3 & 106.68 & 46.76 & 0 & Significant \\
$X_{1}^{2}$ & 36.28 & 1 & 21.38 & 9.37 & 0.012 \\
$X_{2}^{2}$ & 281.11 & 1 & 272.98 & 119.66 & 0 \\
$X_{3}^{2}$ & 2.64 & 1 & 2.64 & 1.16 & 0.308 & Significant \\
Interaction & 109.63 & 36.54 & 16.02 & 0 & Significicant \\
$X_{1} \times X_{2}$ & 17.64 & 1 & 23.19 & 10.16 & 0.019 & Significant \\
$X_{1} \times X_{3}$ & 23.19 & 1 & 68.8 & 30.16 & 0 \\
$X_{2} \times X_{3}$ & 68.8 & 1 & 2.28 & & - \\
Residual Error & 22.81 & 10 & 3.44 & 3.05 & 0.123 \\
Lack of fit & 17.18 & 5 & 1.13 & & Insignificant \\
Pure Error & 5.64 & 5 & & - & -
\end{tabular}

Table 4. Estimated corresponding t- and P-values of the model term coefficients.

\begin{tabular}{ccc}
\hline Model Term Coefficient & $\boldsymbol{t}$-Value & $\boldsymbol{P}$-Value \\
\hline Constant & 132.014 & 0 \\
$X_{1}$ & -13.624 & 0 \\
$X_{2}$ & 27.616 & 0 \\
$X_{3}$ & -12.957 & 0 \\
$X_{1}^{2}$ & 3.061 & 0.012 \\
$X_{2}^{2}$ & -10.939 & 0 \\
$X_{3}{ }^{2}$ & 1.075 & 0.308 \\
$X_{1} \times X_{2}$ & 2.781 & 0.019 \\
$X_{1} \times X_{3}$ & -3.188 & 0.01 \\
$X_{2} \times X_{3}$ & 5.491 & 0 \\
\hline
\end{tabular}

As evident from the calculated $F$ value (144.94) and the low probability value $(P=<0.001)$, the ANOVA of the regression model demonstrated that it was highly significant (Table 3). Values of $P<$ 0.05 indicated that the model terms were highly significant at the $95 \%$ confidence interval. In addition, the lack of fit of the model was insignificant $(P=0.123)$, indicating its accuracy in describing the experimental data. The linear model terms were more significant $(F=372.05$ and $P=<0.001)$ than the square $(F=46.76$ and $P=<0.001)$ and interaction $(F=16.02$ and $\mathrm{P}=<0.001)$ model terms. This indicated that the linear model terms, i.e., the main effects of the process variables, significantly affected the \% chromium RE.

The response surface and contour plots are shown in Figures 3 and 4, respectively. While the response surface plots (Figure 3a) show a clear peak, the plots in Figure 3b,c did not show clear peaks, which suggests that the optimum conditions of the variables were outside the chosen experimental range. For model design, one variable is held at its intermediate level to check the interaction effect of the other two variables. 

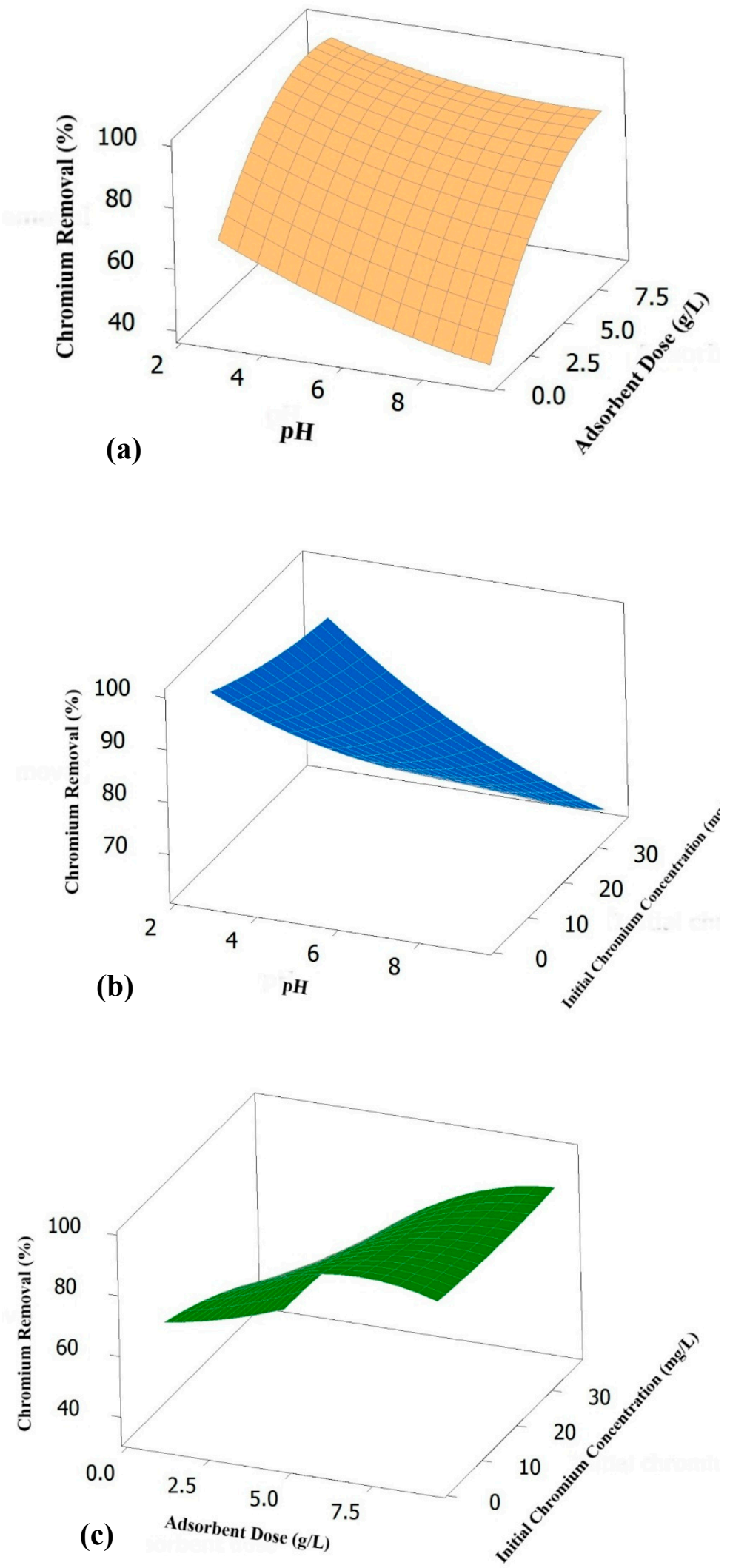

Figure 3. Response surface plots showing: (a) the effects of $\mathrm{pH}\left(\mathrm{X}_{1}\right)$, adsorbent dose $\left(\mathrm{X}_{2}\right)$, and their interaction on chromium RE, with constant initial chromium concentration $\left(X_{3}\right)$; $(b)$ the effects of $X_{1}, X_{3}$, and their interaction on chromium RE (\%); (c) the effects of $X_{2}, X_{4}$, and their interaction on chromium RE (\%). 

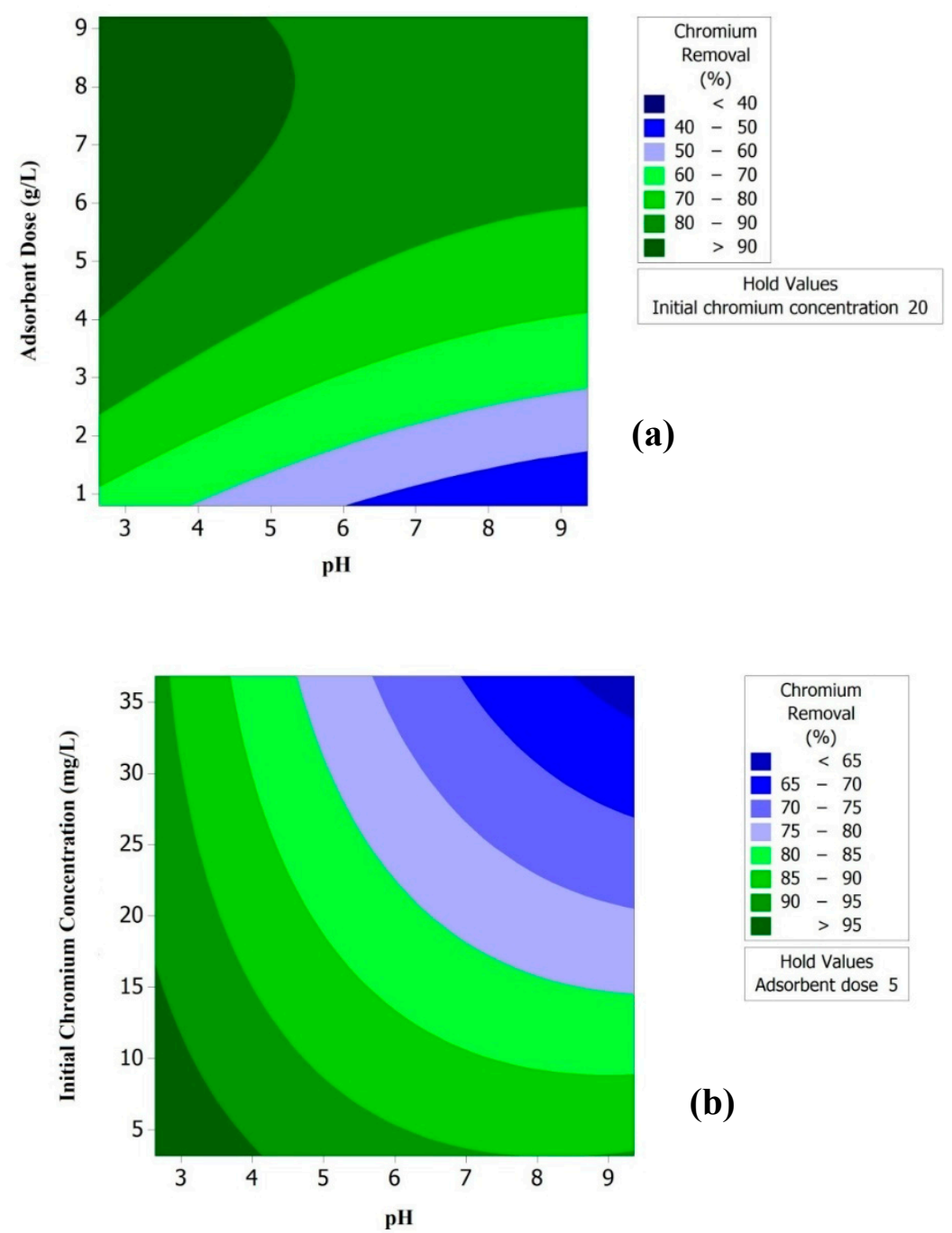

(b)
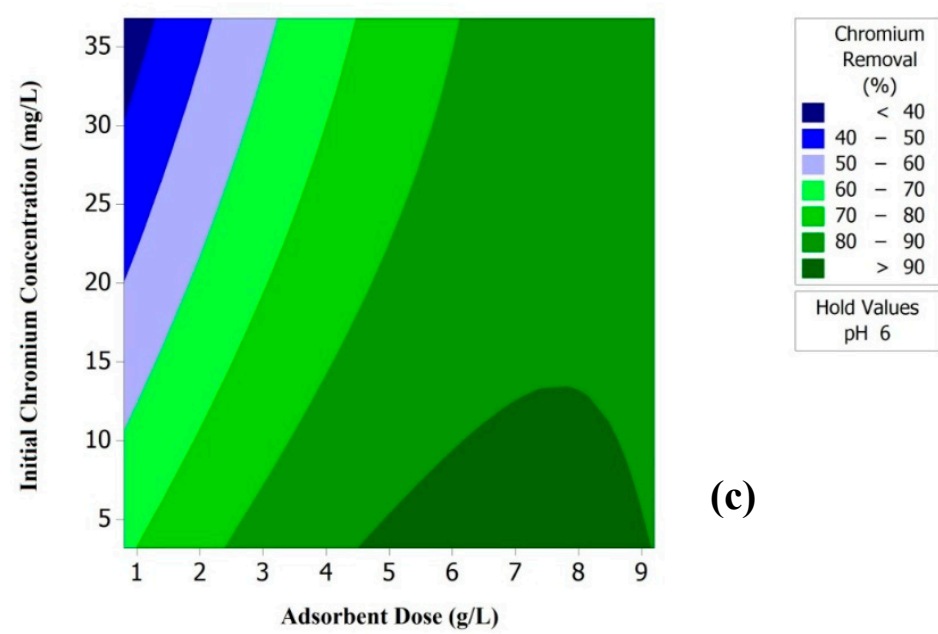

(c)

Figure 4. Response contour plots showing: (a) the effects of $\mathrm{pH}\left(\mathrm{X}_{1}\right)$, adsorbent dose $\left(\mathrm{X}_{2}\right)$, and their interaction on chromium RE, with constant initial chromium concentration $\left(X_{3}\right)$; $(b)$ the effects of $X_{1}, X_{3}$, and their interaction on chromium RE (\%); (c) the effects of $X_{2}, X_{3}$, and their interaction on chromium RE (\%). 
The surface plots shown in Figure 3a-c reveal information on the combined effects of $\mathrm{pH}\left(X_{1}\right)$, adsorbent dose $\left(X_{2}\right)$, and initial chromium concentration $\left(X_{3}\right)$ on the chromium RE. For instance, Figure 3a shows that chromium RE decreases with increasing $X_{1}$ and increases with increase in $X_{2}$. As can be observed from Figure 3a, there is a decrease in the chromium RE with an increase in the $\mathrm{pH}$ from 3.0 to 9.0. This is because of the interaction between the chromium ions and $\mathrm{OH}^{-}$ions. As can be observed from Figure 3b, there is a decrease in the chromium RE with an increase in the initial chromium concentration. Under the optimum conditions of $\mathrm{pH}=2.6$, adsorbent dose $=5 \mathrm{~g} / \mathrm{L}$, and initial chromium concentration $=20 \mathrm{mg} / \mathrm{L}$, chromium $\mathrm{RE}$ of $95.8 \%$ was obtained.

\subsection{Effect of $\mathrm{pH}$ on $\%$ Removal of Chromium}

The $\mathrm{pH}$ of a solution is one of the most important parameters that dictates the sorption of metal ions onto an adsorbent's surface because it determines the adsorbent's surface charge and also affects speciation of metal ions in aqueous systems. It can be observed from Figure $3 a, b$ that the chromium $\mathrm{RE}$ decreased from $70 \%$ to $30 \%$ with an increase in the $\mathrm{pH}$ from 3.0 to 9.0 . The affinities of maghemite for the different species of $\mathrm{Cr}(\mathrm{VI})$ existing at acidic $\mathrm{pH}$ values, namely $\mathrm{H}_{2} \mathrm{CrO}_{4}{ }^{0}, \mathrm{HCrO}_{4}{ }^{-}, \mathrm{CrO}_{4}{ }^{2-}$, and $\mathrm{Cr}_{2} \mathrm{O}_{7}{ }^{2-}$ [31], may be different, and can be attributed to the variation in $\mathrm{RE}$ at different $\mathrm{pH}$ values. Chromium exists in various oxyanionic forms, such as $\mathrm{HCrO}_{4}{ }^{-}$and $\mathrm{Cr}_{2} \mathrm{O}_{7}{ }^{2-}$ in acidic $\mathrm{pH}$ ( $\mathrm{pH} 2$ to 6). Above $\mathrm{pH}$ 6.0, $\mathrm{CrO}_{4}{ }^{2-}$ is the major ionic species. The adsorption of chromium through MNPs turned out to be a highly $\mathrm{pH}$-dependent process. At lower $\mathrm{pH}$ values, increased chromium $\mathrm{RE}$ can be attributed to $\mathrm{H}^{+}$ions being adsorbed by $\mathrm{SO}_{4}{ }^{-}$of sulfate group present on the surface of SDS, which might form complexes with $\mathrm{Cr}_{2} \mathrm{O}_{7}{ }^{2-}$ and $\mathrm{HCrO}_{4}{ }^{-}$through electrostatic interactions [32]. Reduction in chromium $\mathrm{RE}$ at higher $\mathrm{pH}$ is a result of competition between $\mathrm{CrO}_{4}{ }^{2-}$ and $\mathrm{OH}^{-}$ions to occupy the anion exchange sites of the adsorbent. $\mathrm{Cr}^{6+}$ removal at higher $\mathrm{pH}$ might be due to the reduction of $\mathrm{Cr}^{6+}$ to $\mathrm{Cr}^{3+}$ by the electron-rich polymer matrix [33]. A similar observation has been reported using maghemite nanoparticles as the adsorbent, where chromium $\mathrm{RE}$ decreased with increase in $\mathrm{pH}$, which is due to electrostatic interaction between the chromium species and the adsorbent surface [7].

\subsection{Effect of Adsorbent Dose on \% Removal of Chromium}

The effect of adsorbent dose on chromium removal is shown in Figure 3a, c. It was observed that the chromium removal increased from $30 \%$ to $90 \%$ with an increase in the adsorbent dose. This increase in RE is due to the availability of greater number of active sites in the adsorbent. The chromium uptake increased up to an adsorbent dose of $8 \mathrm{~g} / \mathrm{L}$. The $\mathrm{RE}$ of $\mathrm{Cr}(\mathrm{VI})$ ions increased up to an optimum dose $(8 \mathrm{~g} / \mathrm{L})$, beyond which the concentration did not significantly change. This result was expected because increasing the adsorbent dose provides greater adsorption sites for a fixed initial solute concentration. Thus, for an adsorbent dose less than $8 \mathrm{~g} / \mathrm{L}$, the removal of $\mathrm{Cr}(\mathrm{VI})$ ions increased with increasing adsorbent dose. However, after achieving the optimum dose (i.e., dose more than $8 \mathrm{~g} / \mathrm{L}$ ), increasing adsorbent dose led to decrease in the RE because of interfering adsorption sites together. Therefore, there was no further increase in the removal [34]. Similar observations were observed by Nematollahzadeh et al. [35], where catecholamine-coated maghemite nanoparticles are used as the adsorbent for chromium removal. Lower amounts of the adsorbent may achieve acceptable results because of the higher surface area-to-volume ratio [26].

\subsection{Effect of Initial Concentration on \% Removal of Chromium}

The effect of initial concentration on the uptake of chromium was studied at different initial chromium concentrations. The effect of initial concentration on removal of chromium is shown in Figure 3b, c, which shows that an increase in initial chromium concentration decreases the chromium RE. From the figures it can be observed that with an increase in the initial chromium concentration from 5 to $35 \mathrm{mg} / \mathrm{L}$, there is a decrease in the chromium RE from $95 \%$ to $75 \%$. This can be attributed to the fact that that for a fixed adsorbent dosage, a finite and limited number of available adsorption active sites lead to a decrease in percentage removal of $\mathrm{Cr}(\mathrm{VI})$ ions with increasing initial concentration [36]. 
Hu et al. [37] made similar observations, i.e., with an increase in the initial chromium concentration there is a decrease in the chromium RE while using maghemite nanoparticles as the adsorbent.

\subsection{Practical Implications of the Work and Future Research Prospects}

Although it is difficult to compare the adsorption capacity of maghemite nanoparticles with other similar iron oxide nanosorbents (Table 5), due to a variety of conditions in which experiments have been carried out, it was found that the sorption capacity of MNPs (in this study) for $\mathrm{Cr}(\mathrm{VI})$ using equilibrium experiments at $\mathrm{pH} 2.6$ and room temperature $\left(35^{\circ} \mathrm{C}\right)$ is $4 \mathrm{mg} / \mathrm{g}$, which is higher than that reported for maghemite in the literature (i.e., $1.62 \mathrm{mg} / \mathrm{g}$ ) [15]. However, when considering the practical applications of using maghemite nanoparticles, it is important to also understand that these nanoparticles have widespread applications in daily health care items, textiles, cleaning products, biomolecules, and a wide array of professional and recreational items. Therefore, it is important to understand the fate of the nanoparticles in the natural environment. The fate of maghemite nanoparticles not only depends on their physico-chemical properties, but also on the disposal location (i.e., water, solid waste landfills, natural habitats, and wastewater). According to Donia and Carbone [38], assessing the release and behavior or fate of these nanoparticles is very complex due to the large variety of complex interactions they could have with other contaminants and substrates, and also the type of nanoparticles disposed. Thus, the authors recommend the use of appropriate analytical techniques and toxicity studies to characterize the nanoparticles based on their toxicity behavior in water (e.g., using particle chemistry principles) and soil environments. Further studies should also be aimed at performing genotoxic and eco-toxicological assessments of these nanoparticles using representative aquatic species. From a resource recovery view point, it will also be economical to recover the maghemite nanoparticles, as the aggregation and sedimentation behavior of most of the commonly used nanoparticles may occur naturally in the presence of suspended or dissolved substances in water (e.g., of nature organic matter origin). According to Liu et al. 2014 [39], the nanoparticles might undergo precipitation-, adsorption-, and dissolution-based mechanisms in the water bodies; therefore, the authors recommend chemical coagulation and flocculation processes as easy recovery steps based on their settling characteristics. Anew, the use of sophisticated analytical techniques, such as single-particle inductively coupled plasma mass spectrometry (sp-ICP-MS) and multiple fractionation techniques, in combination with light scattering and elemental detection, should also be used to understand the chemical speciation, dissolution, degradation, and surface properties (i.e., due to precipitation and/or adsorption) of the nanoparticles during the chemical transformation process(es) of maghemite nanoparticles in aquatic and soil environments [40]. 
Table 5. Adsorption capacities and mechanisms of chromium (VI) removal by different iron-oxide-based nanosorbents.

\begin{tabular}{|c|c|c|c|c|}
\hline Nanosorbent & Experimental Condition & $\begin{array}{c}\text { Adsorption } \\
\text { Capacity (mg/g) }\end{array}$ & Adsorption Mechanism & References \\
\hline Maghemite & $\begin{array}{c}\mathrm{pH}=2.5, \text { concentration }=5-200 \mathrm{mg} / \mathrm{L}, \\
\text { contact time }=15 \mathrm{~min} \\
\text { temperature }=25^{\circ} \mathrm{C}\end{array}$ & 19.2 & Electrostatic attraction and ion exchange. & [37] \\
\hline Maghemite & $\begin{array}{c}\mathrm{pH}=2.5, \text { concentration }=50 \mathrm{mg} / \mathrm{L} \\
\text { temperature }=25^{\circ} \mathrm{C} \text {, contact time }= \\
10 \mathrm{~min}, \mathrm{pH}_{\mathrm{ZPC}}=6.3\end{array}$ & 17.0 & Electrostatic attraction and ion exchange. & [7] \\
\hline Maghemite & $\begin{array}{c}\mathrm{pH}=4.0, \text { concentration }=0.3 \mathrm{~g} / \mathrm{L} \\
\text { contact time }=120 \mathrm{~min}, \mathrm{pH} \\
\mathrm{ZPC}=6.6\end{array}$ & 1.62 & $\begin{array}{l}\text { Adsorption was controlled by surface } \\
\text { sorption and intraparticle diffusion, followed } \\
\text { by redox reaction. }\end{array}$ & [15] \\
\hline $\begin{array}{l}\text { Montmorillonite- } \\
\text { supported magnetite }\end{array}$ & $\begin{array}{c}\mathrm{pH}=2.0-2.6, \text { concentration }=0.5 \mathrm{~g} / \mathrm{L}, \\
\text { contact time }=120 \mathrm{~min}\end{array}$ & 15.3 & $\begin{array}{c}\text { Adsorption was a physico-chemical process, } \\
\text { including an electrostatic attraction followed } \\
\text { by a redox reaction. }\end{array}$ & [41] \\
\hline $\begin{array}{l}\delta \text {-FeOOH-coated } \\
\text { maghemite }\end{array}$ & $\begin{array}{c}\mathrm{pH}=2.5, \text { concentration range }= \\
10-200 \mathrm{mg} / \mathrm{L}, \text { contact time }=30 \mathrm{~min}, \\
\text { adsorbent dose }=0.1 \mathrm{~g}\end{array}$ & 25.8 & $\begin{array}{c}\mathrm{Cr}(\mathrm{VI}) \text { adsorption onto the } \delta \text {-FeOOH-coated } \\
\gamma-\mathrm{Fe}_{2} \mathrm{O}_{3} \text { is mainly controlled by } \\
\text { outer-sphere complexation. }\end{array}$ & [42] \\
\hline $\begin{array}{l}\text { Mixed magnetite } \\
\text { and maghemite }\end{array}$ & $\begin{array}{c}\mathrm{pH}=2.0, \text { concentration range }=0.5-4 \\
\mathrm{mg} / \mathrm{L}, \text { contact time }=24 \mathrm{~h} \text {, adsorbent } \\
\text { dose }=0.4 \mathrm{~g} / \mathrm{L}\end{array}$ & 2.4 & $\begin{array}{l}\text { Electrostatic attraction between chromium } \\
\text { and magnetite-maghemite mixture. }\end{array}$ & [45] \\
\hline Modified maghemite & $\begin{aligned} \mathrm{pH}= & 2.6, \text { concentration }=20 \mathrm{mg} / \mathrm{L} \\
& \text { contact time }=80 \mathrm{~min}\end{aligned}$ & 4.0 & Electrostatic attraction and ion exchange. & This study \\
\hline
\end{tabular}

\section{Conclusions}

The influence of process parameters, i.e., $\mathrm{pH}$, adsorbent dose, and initial concentration, on chromium removal were investigated by performing statistically designed experiments. The data obtained from ANOVA establishes that the model was highly significant. The results showed that as $\mathrm{pH}$ and initial concentration increases chromium removal decreases, but as adsorbent dose increases chromium removal increases. Concerning the interaction effects, adsorbent dose and initial concentration showed positive effects, while the interaction between $\mathrm{pH}$ and initial concentration showed negative effects. Adsorbent dose also showed a significant squared effect in the experiment. The maximum chromium removal $(95.5 \%)$ was observed at $\mathrm{pH}=2.6$, adsorbent dose $=5 \mathrm{~g} / \mathrm{L}$, and initial chromium concentration $=20 \mathrm{mg} / \mathrm{L}$. The proposed model equation can certainly provide a good estimation of chromium removal in large-scale systems, such as tannery industries. A systematic study on the removal of chromium using MNPs can provide a practical solution for tannery industries located around Vellore (India) to reduce waste discharges, recover useful materials, and reduce or prevent pollution. We would suggest further research to examine the regeneration aspect of MNPs and their subsequent use in order to make them more economical for industrial use.

Author Contributions: Conceptualization, S.K.B.; formal analysis, B.M. and A.V.; investigation, S.S., G.T., and A.R.; methodology, S.K.B.; resources, S.K.B.; supervision, S.K.B.; writing-original draft, S.S., G.T., and A.R.; writing-review and editing, B.M., A.V., E.R.R., and A.P. All authors have read and agreed to the published version of the manuscript.

Funding: The authors gratefully acknowledge the management of Vellore Institute of Technology, Vellore, for supporting this work through the university research seed grant.

Conflicts of Interest: The authors declare no conflict of interest.

\section{References}

1. Dupont, L.; Guillon, E. Removal of hexavalent chromium with a lignocellulosic substrate extracted from wheat bran. Environ. Sci. Technol. 2003, 37, 4235-4241. [CrossRef]

2. WHO Guidelines for Drinking-water Quality. Available online: https://www.who.int/water_sanitation_ health/water-quality/guidelines/en/ (accessed on 4 March 2020).

3. Álvarez-Ayuso, E.; García-Sánchez, A.; Querol, X. Purification of metal electroplating waste waters using zeolites. Water Res. 2003, 37, 4855-4862. [CrossRef] [PubMed] 
4. Palmer, C.D.; Wittbrodt, P.R. Processes affecting the remediation of chromium-contaminated sites. Environ. Health Perspect. 1991, 92, 25-40. [CrossRef] [PubMed]

5. Richard, F.C.; Bourg, A.C.M. Aqueous geochemistry of chromium: A review. Water Res. 1991, 25, 807-816. [CrossRef]

6. Aravindhan, R.; Madhan, B.; Rao, J.R.; Nair, B.U.; Ramasami, T. Bioaccumulation of chromium from tannery wastewater: An approach for chrome recovery and reuse. Environ. Sci. Technol. 2004, 38, 300-306. [CrossRef]

7. Hu, J.; Chen, G.; Lo, I.M.C. Selective Removal of Heavy Metals from industrial wastewater using maghemite nanoparticle: Performance and mechanisms. J. Environ. Eng. 2006, 132, 709-715. [CrossRef]

8. Lazaridis, N.K.; Asouhidou, D.D. Kinetics of sorptive removal of chromium(VI) from aqueous solutions by calcined $\mathrm{Mg}-\mathrm{Al}-\mathrm{CO}_{3}$ hydrotalcite. Water Res. 2003, 37, 2875-2882. [CrossRef]

9. Periasam, K.; Srinivasan, K.; Murugan, P. Studies on chromium(VI) removal by activated ground-nut husk carbon. Indian J. Environ. Health 1991, 33, 433-439.

10. Singh, V.K.; Tiwari, P.N. Removal and recovery of chromium(VI) from industrial waste water. J. Chem. Technol. Biotechnol. 1997, 69, 376-382. [CrossRef]

11. Wang, Y.-H.; Lin, S.-H.; Juang, R.-S. Removal of heavy metal ions from aqueous solutions using various low-cost adsorbents. J. Hazard. Mater. 2003, 102, 291-302. [CrossRef]

12. Owlad, M.; Aroua, M.K.; Daud, W.A.W.; Baroutian, S. Removal of hexavalent chromium-contaminated water and wastewater: A Review. Water. Air. Soil Pollut. 2009, 200, 59-77. [CrossRef]

13. Hayashi, N.; Chen, J.; Seko, N. Nitrogen-containing fabric adsorbents prepared by radiation grafting for removal of chromium from wastewater. Polymers (Basel) 2018, 10, 744. [CrossRef] [PubMed]

14. Zhou, Y.; Wang, Z.; Hursthouse, A.; Ren, B. Gemini surfactant-modified activated carbon for remediation of hexavalent chromium from Water. Water 2018, 10, 91. [CrossRef]

15. Jiang, W.; Pelaez, M.; Dionysiou, D.D.; Entezari, M.H.; Tsoutsou, D.; O'Shea, K. Chromium(VI) removal by maghemite nanoparticles. Chem. Eng. J. 2013, 222, 527-533. [CrossRef]

16. Lin, S.; Lu, D.; Liu, Z. Removal of arsenic contaminants with magnetic $\gamma-\mathrm{Fe}_{2} \mathrm{O}_{3}$ nanoparticles. Chem. Eng. J. 2012, 211-212, 46-52. [CrossRef]

17. Roy, A.; Bhattacharya, J. Removal of $\mathrm{Cu}(\mathrm{II}), \mathrm{Zn}(\mathrm{II})$ and $\mathrm{Pb}(\mathrm{II})$ from water using microwave-assisted synthesized maghemite nanotubes. Chem. Eng. J. 2012, 211-212, 493-500. [CrossRef]

18. Jiang, W.; Cai, Q.; Xu, W.; Yang, M.; Cai, Y.; Dionysiou, D.D.; O'Shea, K.E. Cr(VI) adsorption and reduction by humic acid coated on magnetite. Environ. Sci. Technol. 2014, 48, 8078-8085. [CrossRef]

19. Wang, F.; Yang, W.; Zheng, F.; Sun, Y. Removal of Cr(VI) from simulated and leachate wastewaters by bentonite-supported zero-valent iron nanoparticles. Int. J. Environ. Res. Public Health 2018, 15, 2162. [CrossRef]

20. Ojemaye, M.O.; Okoh, O.O.; Okoh, A.I. Uptake of $\mathrm{Zn}^{2+}$ and $\mathrm{As}^{3+}$ from wastewater by adsorption onto imine functionalized magnetic nanoparticles. Water (Switzerland) 2018, 10, 36. [CrossRef]

21. Ostroumov, S.A. Biological Effects of Surfactants, 2nd ed.; CRC Press: Boca Raton, FL, USA, 2005.

22. Rosen, M.J. Surfactants and Interfacial Phenomena, 4th ed.; John Wiley \& Sons, Inc.: Hoboken, NJ, USA, 2012; ISBN 0471478180.

23. Gao, X.; Chorover, J. Adsorption of sodium dodecyl sulfate (SDS) at $\mathrm{ZnSe}$ and $\alpha-\mathrm{Fe}_{2} \mathrm{O}_{3}$ surfaces: Combining infrared spectroscopy and batch uptake studies. J. Colloid Interface Sci. 2010, 348, 167-176. [CrossRef]

24. Khatoon, N.; Khan, A.H.; Pathak, V.; Agnihotri, N.; Rehman, M. Removal of hexavalent chromium from synthetic waste water using synthetic nano zero valent iron (nZVI) as adsorbent. Int. J. Innov. Res. Sci. Eng. Technol. 2013, 2, 6140-6149.

25. Bagheban Shahri, F.; Niazi, A. Synthesis of modified maghemite nanoparticles and its application for removal of acridine orange from aqueous solutions by using Box-Behnken design. J. Magn. Magn. Mater. 2015, 396, 318-326. [CrossRef]

26. Han, M.J.; Behera, S.K.; Park, H.-S. Anaerobic co-digestion of food waste leachate and piggery wastewater for methane production: Statistical optimization of key process parameters. J. Chem. Technol. Biotechnol. 2012, 87, 1541-1550. [CrossRef]

27. Lkhagvadulam, B.; Tsagaantsetseg, B.; Tergel, D.; Chuluunkhuyag, S. Removal of chromium from a tannery wastewater by using a maghemite nanoparticles. Int. J. Environ. Sci. Dev. 2017, 8, 696-702. [CrossRef]

28. Predescu, A.; Nicolae, A. Adsorption of $\mathrm{Zn}, \mathrm{Cu}$ and $\mathrm{Cd}$ from waste waters by means of maghemite nanoparticles. UPB Bul. Stiint. Ser. B Chem. Mater. Sci. 2012, 74, 255-264. 
29. Montgomery, D.C. Design and Analysis of Experiments, 8th ed.; John Wiley \& Sons: New York, NY, USA, 2012.

30. Gallo-Cordova, A.; Lemus, J.; Palomares, F.J.; Morales, M.P.; Mazarío, E. Superparamagnetic nanosorbent for water purification: Assessment of the adsorptive removal of lead and methyl orange from aqueous solutions. Sci. Total Environ. 2020, 711, 134644. [CrossRef]

31. Pérez-Candela, M.; Martín-Martínez, J.; Torregrosa-Maciá, R. Chromium(VI) removal with activated carbons. Water Res. 1995, 29, 2174-2180. [CrossRef]

32. Babel, S.; Opiso, E.M. Removal of Cr from synthetic wastewater by sorption into volcanic ash soil. Int. J. Environ. Sci. Technol. 2007, 4, 99-107. [CrossRef]

33. Kan, C.-C.; Ibe, A.H.; Rivera, K.K.P.; Arazo, R.O.; de Luna, M.D.G. Hexavalent chromium removal from aqueous solution by adsorbents synthesized from groundwater treatment residuals. Sustain. Environ. Res. 2017, 27, 163-171. [CrossRef]

34. Zhou, Y.-T.; Nie, H.-L.; Branford-White, C.; He, Z.-Y.; Zhu, L.-M. Removal of $\mathrm{Cu}^{2+}$ from aqueous solution by chitosan-coated magnetic nanoparticles modified with $\alpha$-ketoglutaric acid. J. Colloid Interface Sci. 2009, 330, 29-37. [CrossRef]

35. Nematollahzadeh, A.; Seraj, S.; Mirzayi, B. Catecholamine coated maghemite nanoparticles for the environmental remediation: Hexavalent chromium ions removal. Chem. Eng. J. 2015, 277, 21-29. [CrossRef]

36. Bhaumik, M.; Maity, A.; Srinivasu, V.V.; Onyango, M.S. Removal of hexavalent chromium from aqueous solution using polypyrrole-polyaniline nanofibers. Chem. Eng. J. 2012, 181-182, 323-333. [CrossRef]

37. Hu, J.; Chen, G.; Lo, I.M.C. Removal and recovery of $\mathrm{Cr}(\mathrm{VI})$ from wastewater by maghemite nanoparticles. Water Res. 2005, 39, 4528-4536. [CrossRef] [PubMed]

38. Donia, D.T.; Carbone, M. Fate of the nanoparticles in environmental cycles. Int. J. Environ. Sci. Technol. 2019, 16, 583-600. [CrossRef]

39. Liu, Y.; Tourbin, M.; Lachaize, S.; Guiraud, P. Nanoparticles in wastewaters: Hazards, fate and remediation. Powder Technol. 2014, 255, 149-156. [CrossRef]

40. Bundschuh, M.; Filser, J.; Lüderwald, S.; McKee, M.S.; Metreveli, G.; Schaumann, G.E.; Schulz, R.; Wagner, S. Nanoparticles in the environment: Where do we come from, where do we go to? Environ. Sci. Eur. 2018, 30, 6. [CrossRef]

41. Yuan, P.; Fan, M.; Yang, D.; He, H.; Liu, D.; Yuan, A.; Zhu, J.; Chen, T. Montmorillonite-supported magnetite nanoparticles for the removal of hexavalent chromium $[\mathrm{Cr}(\mathrm{VI})]$ from aqueous solutions. J. Hazard. Mater. 2009, 166, 821-829. [CrossRef]

42. Hu, J.; Lo, I.; Chen, G. Performance and mechanism of chromate (VI) adsorption by $\delta$-FeOOH-coated maghemite $\left(\gamma-\mathrm{Fe}_{2} \mathrm{O}_{3}\right)$ nanoparticles. Sep. Purif. Technol. 2007, 58, 76-82. [CrossRef]

43. Yuan, P.; Liu, D.; Fan, M.; Yang, D.; Zhu, R.; Ge, F.; Zhu, J.; He, H. Removal of hexavalent chromium [Cr(VI)] from aqueous solutions by the diatomite-supported/unsupported magnetite nanoparticles. J. Hazard. Mater. 2010, 173, 614-621. [CrossRef]

44. Adegoke, H.I.; AmooAdekola, F.; Fatoki, O.S.; Ximba, B.J. Adsorption of Cr(VI) on synthetic hematite $\left(\alpha-\mathrm{Fe}_{2} \mathrm{O}_{3}\right)$ nanoparticles of different morphologies. Korean J. Chem. Eng. 2014, 31, 142-154. [CrossRef]

45. Chowdhury, S.R.; Yanful, E.K. Arsenic and chromium removal by mixed magnetite-maghemite nanoparticles and the effect of phosphate on removal. J. Environ. Manag. 2010, 91, 2238-2247. [CrossRef] [PubMed]

(C) 2020 by the authors. Licensee MDPI, Basel, Switzerland. This article is an open access article distributed under the terms and conditions of the Creative Commons Attribution (CC BY) license (http://creativecommons.org/licenses/by/4.0/). 